\title{
Potential Implementation of Lightweight Steel Panel System in Affordable Housing Project: Developers Perspective
}

\author{
Misriyanti Saikah ${ }^{1}$, Narimah Kasim ${ }^{1 *}$, Rozilah Kasim ${ }^{2}$ \\ ${ }^{1}$ Department of Construction Management, Faculty of Technology Management \& Business, \\ Universiti Tun Hussein Onn Malaysia, Parit Raja, Batu Pahat, Johor, 86400, MALAYSIA \\ ${ }^{2}$ Department of Real Estate Management, Faculty of Technology Management \& Business, \\ Universiti Tun Hussein Onn Malaysia, Parit Raja, Batu Pahat, Johor, 86400, MALAYSIA \\ *Corresponding Author
}

DOI: https://doi.org/10.30880/ijscet.2020.11.03.007

Received 25 October 2019; Accepted 19 May 2020; Available online 30 June 2020

\begin{abstract}
Utilization of Industrialized Building System (IBS) becomes increasingly dominant in the construction of affordable housing in Malaysia. Theoretically, utilization of IBS system can benefit to reduce the affordable housing price due to the less labor involvement and short constructions time. However, current IBS usage in housing construction still cannot fulfill the affordable housing demand especially in term of price and housing quality. Recent study reveals the lack adoption of IBS component in construction industry mainly caused by poor perception among stakeholder toward the system. Hence, some alterations in the supply of the IBS component essential to being prepared in order to reach the price target to permit all middle-income groups to own the quality house. Construction industry also can explore the other types of IBS system focusing on lightweight types such as wood or steel system which clearly could give benefit to the housing industry on faster works and high housing quality. Due to strong and durable characteristic of lightweight steel panel, it can be seen as an alternative component to be explored to enhance construction practices of affordable housing project. Therefore, the main purpose of this study is to identify the potential of lightweight steel panel system to be implemented for affordable housing project. Accordingly, for the highlight in reducing affordable housing price integrate with provision of good quality housing this research focus on feedback from developer about the proposed lightweight steel panel system. This research conducted an interview with six project managers with more than three years working experience in housing construction project at South of Peninsular Malaysia. Developer's experience in affordable housing project mainly for landed house is coinciding because of lightweight steel panel system suitability for not more than two stories house. The result reveals that, respondent prefer to the advantages of lightweight steel panel system in term of faster installation works, low maintenance work, flexibility and smart construction. In conclusion, the ability of the system to decrease housing price at the same time sustain the desired quality of housing will increase ability and satisfaction for middle-income earner to own the house.
\end{abstract}

Keywords: Affordable Housing, Housing Price, Housing Quality, Lightweight Steel Panel System, Industrialized Building System

\section{Introduction}

Malaysia owns a huge target to be a developed country in the year 2030. Various strategies have been layout by the government to achieve the gold (Yusof, Khan, Yusuf \& Majid, 2019). It includes fulfilling the housing demand for 
low and middle-income earners. The government has launched an affordable housing program through SPNB, PR1MA, and other private developers in the target to increase the number of affordable housing supply. However, after several years the affordable housing supply still insufficient compared to the targeted number of affordable housing demands. Indeed, the targeted of 7 million housing units demand set by department of statistic based on the population closed to 32 million (Department of Statistics, 2016) is too high and Malaysia still facing the issue of housing shortage (Olanrewaju, Lee, Tan, Naoto, Nizamani \& Aziz, 2016). This caused by the housing price and the ability of middleincome earners to buy the house. On average the ability of middle-income earners can buy the house is ranging between R200,001 to RM250,000 with standard size (Bujang, Shape, Abu Zarin \& Ismail, 2017). In order to decrease housing prices, the government has done various activities in reducing the housing price include promotes the utilization of an industrialized building system (IBS) for the affordable housing project.

IBS provides various advantages to the construction industry, especially in a developed country such as Australia, China and Japan (Kim, 2019). Basically, IBS is defined as building components, elements or modules are manufactured under control environment before installation into their final location (Goodier \& Gibb, 2007). The IBS housing system theoretically can increase quality and reduce housing cost and construction time also can give a bright future for the housing construction industry (Harty, Goodier \& Soetanto, 2006; Soetanto, Goodier \& Harty, 2006; Pan, Gibb \& Dainty, 2006). However, there are too many issues faced by Malaysian contractors and developers in utilizing the IBS system in an affordable housing construction project (Ern \& Kasim, 2012). The IBS system as one of the forms of OSM technique introduced by the Malaysian Government since 1966 until now just a few developers and contractors were using the method because of high cost, high risk and high level in setting up the programs (Fathi, Abedi \& Mirasa, 2012).

Indeed, the IBS housing system should have an alternative specification in order to enhance housing construction practices, especially for the affordable housing project. Therefore, this study will emphasize on the development model based on another form of off-site construction focusing on lightweight steel housing construction. The building process starting from the connecting wall and roof structure components in the factory with efficient modern factory assembly line techniques. The steel panel elements are brought to the site for installation and joining activities. These installation steps implemented with the simple procedure and will shorten the projections time. Thus, the lightweight steel panel system is seen as one of an alternatives construction method to increase the housing quality and reduce the construction cost.

\section{Literature Review}

Basically, affordable housing price in Malaysia is at unaffordable housing rate, especially at an urban area. Unaffordable housing rates caused too many unsold housing stock though the demand for housing for the middleincome group exceeds the number of housing supply. In 2016, the Malaysian population estimated 32 million with 7 million housing units (Department of Statistics, 2016). Therefore, Malaysia is facing in about 25 million of housing shortage (Ying, Olanrewaju \& Tan, 2015; Olanrewaju \& Tan, 2018). The huge housing shortage critically needs a balanced strategy between housing price mechanism, housing system delivery, housing quality, and home marketability. Moreover, there is a study that finds out the satisfaction of homebuyers and dwellers with housing in Malaysia is low (Rahman, Wang \& Arrifin, 2015; Mohit, Ibrahim \& Rashid, 2010), this have indicated that the housing industry is not delivering on preferred housing units. There is a lack of preferred quality housing that has led to a spate of completed but unoccupied housing units, preoccupancy obsolescence, high maintenance, high energy costs, and the increment of unsold units, property overhangs and the abandonment of residential real estate.

\subsection{Affordable Housing Project}

Various actions have been taken by the government to increase the number of affordable housing. The government has targeted to solve the ownership issue by introducing the various housing programmers through its Five Year Plans (2016-2020). It is through government initiative to provide affordable housing for middle and low-income earners in both city and rural areas (Economic Planning Unit, 2015). Nowadays, many peoples, especially youngsters, are going to the urban area to earn enough salary to cover their life. However, mostly they are just get started the careers and earn minimal capital. The housing affordability depends on income level (Goh, 1998). In addition, the study by Sulaiman, Baldry \& Ruddock (2005) reveals that the income-earner with monthly income below RM1,500 will have critical housing affordability.

Taking consideration of the affordability issue, these affordable houses should be supplied within the capability of at least for middle-income groups. House is categorized as affordable if the price rate is not the burden of serious financial risks to the household. To avoid serious financial risk put on the monthly payment of rent or mortgage not exceed $30 \%$ (Tan, 2013). However, the housing price rate offers under affordable housing schemes still unaffordable for many peoples. Though for middle-income earners whit at least RM5,000/monthly income cannot afford a suitable house (Bujang, Shape, Abu Zarin \& Ismail, 2017). On the other hand, the only eligible buyer can own a house at the 
price between RM200,001 to RM250,000. The housing price expected to increase over time. One of the reasons for housing price increment is due to the hiking price of construction and raw materials (Lim, 2019), and a shortage of land and rising land prices (Berhad, 2013).

Developers and contractors had to cope with the rising cost of raw material year by year whereas the affordable housing price is stagnant. The distribution of construction cost bared by stakeholders is included construction material in about 64\%; followed by labor cost 20\%; overhead and profit margin 13\%; and plant equipment and other 3\% (CIDB, 2018). Thus, housing material is contributing to the biggest cost of housing construction development while the labor cost is the second largest. The increasing housing material cost and land price caused impossible for the government for lowering the housing price. In other words, peoples are having very slight chances of owning a house due to increasing prices. As a result of the current trend of climbing interest rates, the occupant had to spend most of their monthly income to repay their house installment (Azmi, Bujang, Jiram \& Zarin, 2016). Therefore, the affordable housing price rate for the buyer confides on the margin range of the price offered by the contractor to the developer. The lower housing price can be reached if the developers can gain benefit from the economies of scale in every housing project.

\subsection{Constructions Method of Affordable Housing}

The government is facing pressure to fulfill the housing demand for low and middle-income earners. Since the year 1996, the Malaysian government has a plan to provide sufficient affordable housing for low-income groups with a good quality condition (Maimun, Ismail, Junainah, Razali, Tarmidi \& Idris, 2018). The planning is estimating in about 653,000 affordable housing units as targeted to be built within the year 2016 to 2020 time frames (United Nations, 1996). These houses will be allocated under Program Bantuan Rumah (PBR), Perumahan Penjawat Awam 1Malaysia (PPA1M), Program Perumahan Rakyat (PPR), Perumahan Rakyat 1Malaysia (PRIMA), Rumah Mesra Rakyat 1Malaysia (RMR1M), and Rumah Wilayah Persekutuan (RUMAWIP) programs. But until now, stakeholders of the construction industry especially developers and contractors still unable to reach the target.

Contractors of affordable housing are mostly bounded in utilizing conventional construction methods in housing project implementation. Housing construction project conducted using conventional methods is a technique that has been widely used in the field of residential construction for centuries of years. The method can be defined as fabricating components for the building on site involve the process of installation timber or plywood formwork and steel reinforcement (Haron, Paim \& Yahaya, 2005). The cast-in-situ process is mainly conducted by labor and the overall process is done on-site work. By using the conventional methods, contractors have difficulty to ensure the construction work carried out in accordance with the specified time because of problems related to building quality, the uncertainty of site condition, skilled labor shortage, and bad weather condition. One of the alternatives which can be used to replace this method is by using Industrialized Building System (IBS) where most of the components of a building will be made off-site and manufactured in a factory and brought into the site to be assembled (Blismas, 2007).

Industry advisors and experts frequently inform the construction industry that they should use more offsite and standardization in order to increase quality and reduce cost and time. Indeed, much recent work reporting on offsite construction as one of the key issues in the construction industry (Harty, Goodier \& Soetanto, 2006; Soetanto, Goodier \& Harty, 2006; Pan, Gibb \& Dainty, 2006). Current IBS technology includes precast concrete, interlocking brick, steel framing, lightweight block system, and timber framing system supposedly are not only helping contractors and owners get their buildings faster and more economically. But its also help reduce construction waste and produce high energy efficiency which result in a long-term benefit to projects (CIDB, 2003). CIDB (2003) has categorized the types of IBS systems in the housing construction market as shown in Table 1.

Table 1 - Types of IBS and Structure Elements in Housing Construction Market (CIDB, 2003)

\begin{tabular}{lll}
\hline System & $\begin{array}{c}\text { Structure } \\
\text { Elements }\end{array}$ & \multicolumn{1}{c}{$\begin{array}{c}\text { Structure } \\
\text { Elements }\end{array}$} \\
\hline Precast concrete system & Column Beam & Wall Slab \\
Reusable formwork system & Column Beam & Wall Slab \\
Steel Framing Systems & Column Beam & Rood Truss \\
Prefabricated timber framing systems & Column Beam & Rood Truss \\
Blockwork systems & Column Beam & Wall \\
\hline
\end{tabular}

IBS consists of precast component systems, fabricated steel structures, innovative mold systems, modular block systems, and prefabricated timber structures as construction components (CIDB, 2003; CIDB, 2004). Parts of the building that difficult to build and time-consuming to be cast on site are designed and detailed as standardized components at the factory and transported to the site to be assembled (CIDB, 2004). Onsite casting activities in IBS utilize innovative and clean mold technologies (CIDB, 2007). According to Pan, Wong \& Hui (2007), construction industry in developed countries has started to adapt IBS as a method of attaining better construction quality and 
productivity, reducing risks related to occupational safety and health, alleviating issues for skilled workers and dependency on manual foreign labor, and achieving the ultimate goal of reducing the overall cost of construction. To date, IBS in Malaysia is dominated by precast concrete, reusable formwork and block work system expected can offer minimal wastage, fewer site materials, a cleaner, and neater environment, controlled quality and lower total construction costs (Pan, Gibb \& Dainty, 2008).

However, the current types of IBS system in Malaysia is mainly related to multi-story brick masonry and high-rise reinforced concrete residential buildings system involving a high degree of fabricated offsite and on-site work. Additionally, the advantages of IBS in term of economic aspects are not well documented in Malaysia and past finding indicates that IBS is more expensive due to fierce competition from the conventional building system (Haron, Hamzah \& Mahanim, 2009). While in terms of quality from the client's perspective towards the IBS system is still at a lower level. It is due to some of the developers experiencing in the IBS system much slower than the conventional system due to the lack of skill IBS workers. Other problems are such improper site conditions, maintenance issue and inflexibility for renovations work. Therefore, it is an urgent need for Malaysia's housing industry to realize the shift from heavy concrete to the lightweight steel structure of the IBS system to be adopted in the affordable housing project. As a relatively new housing system with its superior advantages, steel residential housing will play a more and more important role in Malaysia.

Thus, the iron and steel industry is a key driver for the industrial and economic growth in Malaysia. The iron and steel industry has a large linkage to supply basic raw materials and components to different sectors in the Malaysian economy, including the construction industry, automotive industry, electrical/electronics industry, machinery, and engineering fabrication industries. The outlook forecast for this industry is to continue growing at a rate of 5 to $7.5 \%$ in 2011 (Malaysia Industrial Development Authority, 2011). There are also have positive demand 16\% increase in steel as one of the major constructions material for building and engineering work from 2015 to 2018 in Malaysia (CIDB, 2018). Based on the positive development of the steel industry, Malaysia has strong opportunities to diversify the construction method of affordable housing. Many developed countries such as Japan and China have explored the lightweight steel material as one of the preferable housing construction systems for residential housing development (Cheng, Zhao \& Chen., 2011). Indeed, this country already has the best cost mechanism in light steel frame housing development. With the great support for construction steel of state government as well as the large demand for the housing industry, the prospects for lightweight steel panel system building are very promising and pending for further development.

\subsection{Potential Implementation of Lightweight Steel Panel System}

\subsubsection{Faster Installation Work}

The lightweight steel panel construction system has given great chances for the housing industry to have an agile housing construction system. There is a lot of developed countries such as China, United Kingdom (UK) and Japan are pioneer in lightweight steel panel system utilization in housing construction. For another developing country like Nigeria believe the further utilization of the IBS system can give advantages to the stakeholders include less wastage on site, faster construction, quality improvement and reduction in wet trades (Kolo, Rahimian \& Goulding, 2014). Thus, the lightweight steel panel system as one type of IBS housing system will give more advantages to overcome the disadvantages of the current IBS housing system. The system is similar to other IBS material which used precise steel material has increase speed construction and gives greater economic performance (Andrade, Bragança \& Camoes, 2016). While, the need for shorter construction times with limited space, greater quality building, reduction of on-site labor time and cost can be achieved by simple construction housing method (CIDB, 1999). Faster construction work of the LSP system will give contractor advantages in time and labor reduction. The reduction of labor cost as the secondlargest construction cost will give chance to developers gaining discount housing prices from the developer (CIDB, 2018). Therefore, this strategy can give advantages for customers to buy the house at a lower price.

In addition, the economic privileges of lightweight steel panel system can only be achieved by several factors to avoid project delay includes good management in material delivery to site, good track payment to suppliers, faster payments from clients to main contractor, enough foreign and local workers in the market and capability of site management to organize site activities (Kadir, Lee, Jaafar, Sapuan \& Ali, 2005). Pan (2006) also affirms that there are a lot of significant drivers for utilizing new methods of the IBS system are includes skill shortages, achieving great cost and time, attain high quality and minimizing on-site duration. Russell, Weston, Goswami \& Doll (2011) have held the principles that residential construction by using the IBS system under a controlled environment can reduce material waste, and construction cost while increasing efficiency. This principle is used to design and construct flex houses in the target that prefabrication of the house can minimize site preparation time, waste and safety concerns and maximizes economy, quality control, efficiency, and safety during the housing construction process. Furthermore, as shown in Japan and China, the advantages of utilizing a lightweight steel panel as prefabricated and preassembly systems are estimated to increase by $86 \%$ in the last 15 years. The advantages include earthquake resistant structures can be constructed with low investment and less time, reduce the waste produced in sites, reduction on environmental risk, reduce the number of labor and worker can assure their safety (Paudel, Dulal, Bhandari \& Tomar, 2016). 


\subsubsection{Maintenance Work}

This is a fact that a building is being more to process instead of being a product. House building exposed all the time to any type of weather condition such as hot and cold climate. Changing on cold and hot weather climates caused by house becomes obsolete, inappropriate, difficult to use, and burden to maintain, may also do not comply with requirements and regulations and falls out of fashion. Thus, it is put pressure on the owner to allocate some money for maintenance work. Based on the norm, it is very important to make a lightweight steel panel system as a product that has criteria with simple maintenance work, refurbishment, reconstruction, modernization, adaptation, addition and in the end, unavoidable demolition and removable (Brezer, 2014). The lightweight steel panel system must be easily entered into easy modification because of overall joining system is using fix and screw. Further, the system which has reuse and recycles specification will give extra-economic advantages to the house owner.

In fact, the used of lightweight steel panel system such cold-formed steel materials type have become give more cost competitiveness in recent times, with the better-expected performance the system can provide the economic platform in construction of low maintenance residential house (Cole \& Gad, 2017). In addition, the house built using cold-form steel is essential for disaster-prone areas in Australia, where a robust structure of this nature is desired. Indeed, a lightweight steel panel system based on galvanized material equip a much higher level of protection, and the risk of moisture within the insulated building envelop in modern building construction is largely eliminated (Lawson, Ogden, Pedreschi \& Popo Ola., 2005). Normally, the reaction of the surface of steel with are and airborne pollutants will form the complex series of rust. However, the process just happens in a cold environment and no protection required under warm environments like Malaysia (Lawson, Popo-Ola, Way, Heatley \& Pedreschi, 2010). In other point is, the performance of lightweight steel panel product development by using galvanized (zinc-coated) steel components within warm-frame applications is very good. The findings by Lawson, Gorgolewski \& Grubb (2003) show that the predicted design life of the standard G275 coating, based on the measured loss of zinc from the strip steel is over 200 years, provided that the building envelope is well insulated and properly maintained. Therefore, the utilization of a lightweight steel panel system will lower the maintenance cost could be bared by the owner in the long term.

\subsubsection{Physical Appearance}

Normally, the human will buy a product based on physical appearance. Clients will look forward to the contact of physical, appearance, size and price while choosing the house. Nonetheless, the stakeholder has placed higher importance on the physical aspects in considering the permanent residential purpose and put nonphysical aspects as an important part of developing temporary residential or economic purposes (Gan, Zuo, Wen \& She, 2019). The provision of housing which has decorative and modern looks design will give strong attention to the clients. This because the attractive color of the house can enhance the client's satisfaction. According to Pan, Gibb \& Andrew (2007), there are several factors associated with clients satisfaction includes; manufacturer or supplier capacity and competency, building images of occupiers that the building increases the team/clients confidence, prefer to industrial capacity, and also the choices of building color and texture enhances enjoyment. The entire subject link on each other, such as current IBS precast normally developers need to pay attention to leakage problem in the jointing system.

In IBS precast application, a developer faces the maintenance issue before giving the house to the owner. Some tenancy releases to clients between 6 months and some until two years. In this case, leakage issues may occur in the wall jointing system. Leakages problem on the wall will give other complication may follow includes dampness and corrosion also give bad physical feature to the house appearance (Mydin, Sani \& Taib, 2014). Hence, in the advance of recent technology, some country has developed the decorative wall metal panel and extrusion trim configures in clip type into the plurality of connector (Kwan, 2016). The decorative wall panel installed as part of the modular housing type. This can further enhance not for the construction method only but more than that towards the quality and physical appearance of housing itself.

\subsubsection{Flexibility}

The world of the housing industry has to review IBS from various points. To date, recent studies have incorporated the adaptability and flexibility concept in design and developing housing. Flexibility housing concept is greatly important in the designation of affordable and economic home to create the houses which balance with price, size and owner needs. The owner of the house sooner or later needs to renovate the house whether expected, even planned or unexpected which normally caused by many reasons includes catastrophes, tiring of material, the collapse of the structure, pest invasions. Another reason is influence by dweller promotion such as planning the modification of the housing structure, higher income, desire for higher standards living status and following trends. On top of that, the owner also needs to plan a new design of house layout because of the increased number of family members (Brezar, 2014). They may conduct small renovation to cope with the problem by; demolish assisting wall (make a small room bigger); inserting new partition wall (to make two rooms out one); cutting a new door (to provide alternative access), and walling up a door (to assure privacy). Thus, there are robust needs to encourage the utilization of the IBS system 
which can flexible for future changes and adaptation possible. However, normally building in Malaysia is not developing with flexible specification IBS product especially for terrace and bungalow houses.

Recent studies have been come out with a new idea based on a new doctrine of flexibility and adaptability. The new doctrines are covers several concepts of modification: allowing building parts to be changed or move independently, separating a structural component from the building envelope and technical equipment and introducing new modern materials (Brezar, 2014). Hence, the industry shall extract the benefit from the current technology of IBS (Rahim, Hamid, Zen, Ismail \& Kamar, 2012) to develop the lightweight steel panel system which more adaptable and flexible towards client needs. In fact, both adaptability and flexibility are two important components should be given emphasis in the IBS-housing development effort (Habraken, John, Teicher \& Jonathan, 2005). Flexibility is crucially important to the owners for the purpose of renovation or future modification. The house built in a flexible manner will give extra advantages to the owner in renovation planning. Flexibility and adaptability concepts can be inserted in a lightweight steel panel system configuration from the early stage of housing development. Based on the housing layout plan designer can set an important point of the flexible joint system. This also one of the strategies proposed by Haron, Rahman, Wang \& Wood. (2015) which encourages IBS designers to allow flexibility in IBS architectural design as well as other construction systems. The flexible joint system could allow the owner to future modifications under optimal cost. In fact, lightweight steel panel system configuration consists of both elements of flexibility and adaptability on building through the use of analytical tools which can contribute better control of building system architecture that enables easier, and less costly, also user-driven adaptations (Schmidt, Vibaek \& Austin, 2014).

\subsubsection{Smart System}

The lightweight steel panel system introduces to the industry towards the adaptation of holistically IBS housing construction. The holistic approach of a lightweight steel panel system can be seen from the ability of the system to help fulfill not individual needs only but also for the stakeholders and country. Various benefits can be enjoyed by many layers of units such; contractors can run project without repetition work problem; developer received a house without crack risk problem; encourage local builder to enter with the new method of construction which less 3D (difficult, dangerous and dirty) job; clean and neater construction site; and less environment impacted by waste generation, preserving natural resources, less foreign labor involvement, higher the local labor incomes and reduction on carbon dioxide release (Mydin, Sani \& Taib, 2014; CIDB, 2007). The ability of a lightweight steel panel system to eliminating overall construction risk will enhance local IBS as a smart system. This also can increase the satisfaction of buyers in accepting IBS housing material. In the case of, buyers always skeptical about the IBS material used for the housing construction due to the crack risk in jointing and unadoptable housing system.

In addition, Blismas, Pasquire \& Gibb (2006) and Gibb \& Isack (2003) have found out that client's perceptions toward the IBS system are: less snagging, less site disruption and highly in dry work construction. Some developers may worry about the deterioration of the construction site, this because worried of some clients will come to the site to see the process of the construction project. The messy site condition may contradict the theory or client's understanding of the IBS system which clean and neater. Moreover, Construction Industry Development Board (CIDB) has pushing utilization of the IBS system for the sake of matters associated with safety construction on-site work to a working environment cleaner, more convenient and more organized (Mydin, Sani \& Taib, 2014). No wonder, a certain country is in a triple advance configured IBS system to modular and hybrid system concepts such United Stated preferred modularity orientation and Japan as the country most oriented to integration (Yu, Yashiro, Yoshida \& Qiu, 2015). Current trends in modular housing are by configures the structural steel studs in modular housing module as well as lightweight steel panel system which are consist of a double layer of gypsum board and followed by inserting mineral wall in the cavity wall (Kim, 2019)

\subsubsection{Benefit of Lightweight Steel Panel System Implementation}

The benefits of a lightweight steel panel system as described in this literature can be an important requirement in the development of a framework based on the client's needs. All the criteria are based on research findings from several countries. The experience of development and developing countries in solving the related to affordable housing ownership issues can be used in dealing with a similar issue in Malaysia. The findings are summarized in Table 2 as follows. 
Table 2 - Summary of Benefits of Lightweight Steel Panel System Implementation

\begin{tabular}{|c|c|c|}
\hline Main Factor & References & Benefits \\
\hline Faster Installation Work & $\begin{array}{l}\text { Kolo, Rahimian \& Goulding } \\
\text { (2014); Andrade, Braganca, \& } \\
\text { Camoes (2016); CIDB (1999), } \\
\text { Kadir, Lee, Jaafar, Sapuan \& Ali. } \\
\text { (2005), Pan(2005); Russell, } \\
\text { Weston, Goswami, \& Dol (2011); } \\
\text { Paudel, Dulal, Bhandar \& Tomar } \\
\text { (2016). }\end{array}$ & $\begin{array}{l}\text { - Faster construction } \\
\text { - Increase construction speed with steel usage } \\
\text { - Shorter construction time by a simple method } \\
\text { - Increase IBS component utilization } \\
\text { - Increase efficiency }\end{array}$ \\
\hline Maintenance Work & $\begin{array}{l}\text { Brezar (2014); Cole \& Gad, } \\
\text { (2017); Lawson, Gorgolewski, \& } \\
\text { Grubb (2003). }\end{array}$ & $\begin{array}{l}\text { - Simple maintenance work of steel frames house } \\
\text { - Low cost of maintenance work }\end{array}$ \\
\hline Physical Appearance & $\begin{array}{l}\text { Gan, Zuo, Wen, \& She (2019); } \\
\text { Pan, Gibb, \& Andrew (2007); } \\
\text { Mydin, Sari, \& Taib (2014); } \\
\text { Kwan, 2016) }\end{array}$ & $\begin{array}{l}\text { - New physical aspects in residential housing } \\
\text { - New building images increase client confident } \\
\text { - Decorative wall of modular housing }\end{array}$ \\
\hline Flexibility & $\begin{array}{l}\text { Brezar, 2014; Rahim, Harrid, Zen, } \\
\text { Ismail \& Kamar (2012); Habraken } \\
\text { (2005); Haron, Rahman, Wang \& } \\
\text { Wood (2015). }\end{array}$ & $\begin{array}{l}\text { Increase flexibility and adaptability } \\
\text { Encourage flexibility in architectural design }\end{array}$ \\
\hline Smart System & $\begin{array}{l}\text { Mydin, Sari, \& Taib (2014); } \\
\text { CIDB (2007); Blismas, Pasquire } \\
\text { \& Gibb (2006); Gibb \& Isack } \\
\text { (2003); Mydin \& Taib (2014); } \\
\text { Yu et al. (2015); Kim (2019) }\end{array}$ & $\begin{array}{l}\text { - Safety, cleaner convenient and orgarized } \\
\text { - A modular and hybrid housing system } \\
\text { - Steel modular housing }\end{array}$ \\
\hline
\end{tabular}

\subsection{Research Methodology}

This study applies methodological pluralism, considering housing affordability and quality as part of an interdisciplinary study that can be enriched by the use of multiple research methods. Methodological pluralism is defined as the use of different but complementary research methodologies leading to a coherent, cumulative knowledge building and embracing holistic possibilities, to find value in methodological diversity (Fiske \& Sheweder, 1986; Kirsch \& Sullivan, 1992). In addition, it can be defined as the belief "that no single approach to research is best overall; rather what is more important is that the methods have to be appropriate for the questions under investigation" (Baker, Gersten \& Lee, 2002). In a mature state of a pluralist discipline, the value of one's own approach should be possible to state without needing to define it in contradiction or opposition to other methods (Barker \& Pistrang, 2005; Jansen, Coolen \& Goetgeluk, 2011).

In particular, the authors have ensured that the participants are aware of the aims, objectives, and methodology of the study. The research conducted a study in utilizing semi-structured interviews to examine the potential factors of the lightweight steel panel system implementation in an affordable housing project. An in-depth interview is conducted with the project manager with more than three years of working experience in the developer's subsidiary which develops an affordable housing project. The current construction practices for affordable housing projects were the focus of this research; therefore, the research was only restricted to construction practices for affordable housing only does not involve other types of housing.

The interview technique in collecting qualitative data is by face-to-face interview approach. This technique will allow the researcher to get real data for the research (Aliyu, Kasim \& Martin, 2011). The answers given by individuals more subjective base on knowledge and experience own by them. Response from respondents is recorded using recording tape and time duration in the interview session were varied commonly from twenty minutes to forty-five minutes depends on circumstances. Since the data is collected only involve six respondents content analysis was used for analyzing the data. The recorded interview which converted into a form of text is coded or broken down, into manageable categories on a variety of levels--word, word sense, phrase, sentence, or theme and then examined using one of content analysis' basic methods; relational analysis. Through the analysis proses, the benefits of lightweight steel panel system implementation for affordable housing have revealed and can be made as a benchmark in the development 
of systems framework. Therefore, the developer's feedback is important to enhance housing construction practices for affordable housing based on the client's expectation.

\section{Result and Discussion}

\subsection{Respondents Background}

Respondents for this research are focused on the project manager which has more than three years of working experience in developers firm which has conducted an affordable housing project. They gain experience based on the main project management principles to organize, lead, plan and control the whole project implementation process. The project manager handles the entire project includes preparation of site plan, project financing plan, manages the design and construction teams including architects, general contractors, engineers, construction managers and other consultants to ensure adherence to project budget and schedule, cost containment and quality control.

Table 3 shows the organization types, position, experiences years, housing value, a current project undertaken and the current construction method for the affordable housing project. From the schedule, we know that all of the respondents in a position as a construction project manager. Experience more than three years is crucial and will give a clear picture of the subject matters. The selection of the project manager was vital to this research due to their experience involvement in planning, implement and controls the affordable housing construction project. This because project managers in developers firm have wide experience in dealing with a contractor as an implementer and also buyers as end-user of the IBS system. In addition, the successful implementation of the IBS system in Malaysia specified based on client-driven (CIDB, 2006).

Table 3 - Respondents Background

\begin{tabular}{|c|c|c|c|c|c|c|}
\hline $\begin{array}{c}\text { Respondent } \\
\text { (R) }\end{array}$ & Organization & Position & Experiences & $\begin{array}{c}\text { Housing Value } \\
\text { (RM) }\end{array}$ & $\begin{array}{c}\text { Project } \\
\text { Undertaken }\end{array}$ & $\begin{array}{c}\text { Construction } \\
\text { Method }\end{array}$ \\
\hline R1 & Developer & $\begin{array}{l}\text { Project } \\
\text { Manager }\end{array}$ & 8 years & $350,000 \&$ below & $\begin{array}{l}\text { Semi detach } \\
\text { house }\end{array}$ & $\begin{array}{l}\text { Conventional } \\
\& \text { precast } \\
\text { concrete }\end{array}$ \\
\hline $\mathrm{R} 2$ & Developer & $\begin{array}{l}\text { Project } \\
\text { Manager }\end{array}$ & 5 years & $150,000 \&$ below & Terrace house & $\begin{array}{l}\text { Conventional } \\
\& \text { block work } \\
\text { system }\end{array}$ \\
\hline R3 & Developer & $\begin{array}{l}\text { Project } \\
\text { Manager }\end{array}$ & 4 years & $150,000 \&$ below & $\begin{array}{l}\text { Bungalow \& } \\
\text { detach house }\end{array}$ & $\begin{array}{l}\text { Conventional } \\
\& \text { precast } \\
\text { concrete }\end{array}$ \\
\hline R4 & Developer & $\begin{array}{l}\text { Project } \\
\text { Manager }\end{array}$ & 10 years & $350,000 \&$ below & Terrace house & Conventional \\
\hline R5 & Developer & $\begin{array}{l}\text { Project } \\
\text { Manager }\end{array}$ & 5 years & $200,000 \&$ below & $\begin{array}{l}\text { Bungalow, } \\
\text { detach house }\end{array}$ & $\begin{array}{l}\text { Precast } \\
\text { concrete }\end{array}$ \\
\hline R6 & Developer & $\begin{array}{l}\text { Project } \\
\text { Manager }\end{array}$ & 15 years & $200,000 \&$ below & $\begin{array}{l}\text { Semi \& detach } \\
\text { house }\end{array}$ & Conventional \\
\hline
\end{tabular}

\subsection{Potential Implementation of Lightweight Steel Panel system}

This study frames the requirement of advantages of lightweight steel panel system implementation in the affordable housing project. These advantages element based on the developer's overview shape the way of design and material specification of lightweight steel panel system development. Developers as a center between contractor and customer have shared the most important part to be concerning in lightweight steel panel system development. How developers look at the advantages of lightweight steel panel system as guidance to the system acceptance. This is an important part in which to develop the lightweight steel panel system which can increase the marketability and sustainability of the system. As mentioned above, the preferences of the advantages of the lightweight steel panel system can be themed into; (i) faster installation work, (ii) maintenance work, (iii) physical appearance, (iv) flexibility, and (iv) smart system.

\subsubsection{Faster Installation work}

The new lightweight steel panel system development must be framed by fulfilling the second rules housing construction which can erect faster by labor. The majority developer remark lightweight steel panel system as part of the IBS system can give contractors extra advantages on short construction time. By short construction time, contractors will soon give developers less price offer in housing development. So, the developer can be lowering the 
housing price by receiving the construction reduction cost. Respondent R1, R3, R4, and R5 have given a clear argument about this matter.

“..The advantages of panelized housing are faster installations work and lower cost. The housing quality depends on the material of the panel system itself." Respondent R3.

“....We prefer the IBS system which can be finished faster. Normally, the contractor will finish the housing to follow our target. If we target to finish the house in two years, so then we will make sure it will be finished in two years. The problem is sometimes, by using a conventional system there is a rise of extra work to be fixed." Respondent R4.

"...I think faster installation work is so important, especially we as a developer which target for the big scale of housing delivery. From that, we can save time and cost. Because we have own Acquisition Procurements Department Unit have revealed that there is a difference between procure 1 unit and hundred units of house. The price will be reducing. That's why I think it is important because our organization encourages our contractor to used IBS." Respondent R5.

The building strategies such rapid housing-rebuilding, short delivery time, control the building process, narrow and clear specialized jobs, and avoiding complexity still be the main issues in the construction industry (Jovanovic, Grbic \& Petrovic, 2011). The majority of respondents have realized that the first cost reduction is on less labor consumption. The second cost reduction is by the short duration of the housing construction project. The ability of a lightweight steel panel system to shorten housing construction time without defect problem is more preferable than others. Pan, Wong \& Hui (2007) urged that the direct cost of utilization of lightweight partitions on apartment construction is less $8.2 \%-13.9 \%$ compare to conventional partition. More cost reduction which further saves up to $24 \%$ by other factors like the decrement in loading, enlarged net room area, uncomplicated finishing and fast construction time. Another point is the further study exposed that the utilization of prefabricated modular and steel structure also can lower the total cost of the project by $12 \%$ as compared to the conventional housing system such concrete hollow brick (Paudel, Dulal, Bhandari \& Tomar, 2016).

In fact, the total cost reduction by lowering labor and other cost has increased the usage of the light steel frame in a residential housing project in Japan and China by 86\% since the year 1995 to 2010 (Lawson, Popo-Ola, Way, Heatley $\&$ Pedreschi, 2010). The scenario shows that Japan and China have been faced a positive growth in light steel frame housing construction over 15 years. On this basis, Malaysia should have been readily accepting the new lightweight type of materials for housing construction, especially for low and medium-cost houses. Although Malaysia is still new in the steel industry, Malaysia has received a positive demand $16 \%$ increment on steel as one of the major constructions material for building and engineering work within 2015 to 2018 (CIDB, 2018). However, respondent R6 stress that the important is to find an affordable steel material in developing the LSP system. This is because of various steel available in the steel market nowadays.

On top of that, there are several aspects could be a concern in lightweight steel panel system framework development in order to fulfill faster construction rules without compromising the housing quality. Housing quality focusing on maintaining the comfort level of the occupant can achieve through superb housing layout and design (Rahadi, Wiryono, Koesrindartoto \& Syamwil, 2015). Importantly, the design and layout of the house can give the dwellers a sense of calmness and good ventilation (Yap, Yong, \& Skitmore, 2019). Thus, the design and layout department plays an important role in designing affordable housing which has a maximum comfort level and at the same time can fit with lightweight steel panel system mechanical performance. Otherwise, it does will increase the tendency of housing abandonment which further will increase maintenance and refurbishing cost also occupier dissatisfaction (Olanrewaju, Lee, Seong, Mine \& Teng, 2017). Therefore, the affordable housing arena can further give opportunities to the steel and modular house building type due to the ability to the saving time, money and the high safety of the people as well (Paudel, Dulal, Bhandari \& Tomar, 2016).

\subsubsection{Maintenance Work}

In order to obtain optimization of the overall cost of lightweight steel panel system performance in an affordable housing project is by reduction on extra cost and housing maintenances before selling the house. Normally, developers found that contractor delay in house finish submission because of extra cost incurred especially by utilizing the conventional system. In other point is, some houses cannot sell immediately after finish and the developer will bear maintenance costs within the period. Respondents R2, R4 and R6 have mentioned about extra cost and maintenance issue as follow.

"..We can convince the customer that the material system we used is a lightweight steel panel system which is less maintenance over the years. Such if we used the conventional system we can guess that the period of wall defects is under ten years only. Normally, the liking problem arises within ten years for the conventional housing system. But, if we used this lightweight steel panel system as a prefabricated system and the installation conducted in a proper manner, it will lower the maintenance cost." Respondent R4.

"..We have very little maintenance. It is really compulsory in two years. That we call is the defects liability period. But at that time we have fewer defect cases. Just for small maintenance like roofing problem, the quality of housing constructions must be in good." Respondent R2. 
“..We do not know how to reduce the cost of steel, because normally steel is expensive. Because you need a treatment, but it is possible if you used aluminum type of material for the exterior wall. I also agree if you used the material with color bonds such as roofing sheet types. My suggestion, if you want to reduce the cost you can use the roofing sheet metal material with thickness around $3.05 \mathrm{~mm}$ for exterior wall. This type of material you can use for the panelized system." Respondent R6.

Accordingly, developers urge by utilization of the current conventional system they will face the obsolescence issue after one year or two years finish housing construction. This is caused by some houses just can sell several times. It is probably caused by the way of affordable housing constructed by contractor managing with tight budget and schedule which have resulted in poor quality housing (Gan, Zuo, Ye, Chang \& Zillante, 2016). As a result of obsolete houses, the developer probably should allocate their saving to the maintenance of the house before giving tenant to the buyer. Many cases of defect problems faced by the developer in housing development are leaking pipes, improper water supply system, cracks in the concrete wall (cracking in jointing system for IBS precast concrete), doorknob failure and concrete wall dampness (Rahman, Wang, Wood \& Khoo, 2014). The dampness of the concrete wall gives a huge burden to developers in facing the maintenance problems.

Indeed, moisture on the concrete wall will cause other problems such as molded growth and cracking on the wall. Thus, the usage of lightweight steel panel material can help reduce some of the maintenance problems bared by the developer. Nonetheless, as respond by respondent R6 suggest doing a lot of treatment on the metal wall especially for the exterior side. Respondent R6 also agreed for the usage of the metal wall for exterior rather than cement board or other materials which expose to the crack in jointing. Alternatively, the lightweight steel panel system based on galvanized material equip a much higher level of protection, and the risk of moisture within the insulated building envelop in modern building construction is largely eliminated (Lawson, Gorgolewski \& Grubb, 2003). Lawson also urges that predicted design life of galvanized metal type of the standard G275 coating based on measured of zinc from the strip steel is over 200 years. Therefore, the utilization of a lightweight steel panel system has eliminating maintenance work by the developer for crack risk in jointing especially before handover the housing to a buyer.

\subsubsection{Physical Appearance}

Generally, any completed house construction will be certified ready to finish once the physical perfection on the appearance has been achieved. In this case, developers need to follow every development phase of the house to ensure the standard of housing quality will be achieved. Respondents R1, R3, R4, and R6 agree that quality of physical appearance is important especially to fulfill the Quality Assessment in Construction (QLASSIC) under the Construction Industry Development Board (CIDB) standard requirement. The QLASSIC standard developed by CIDB Malaysia is important as a benchmark in analyzing building quality. Sulaiman, Jusoh, Ying \& Soheilirad (2019) stated that, adherence to the QLASSIC standard by the developer in order to ensure homebuyer's satisfaction with the quality of the completed house.

"..We must ensure the contractor should be passed through QLASSIC audit conducted by CIDB to achieve the standard requirement of building quality." Respondent R5.

"..Many complaints are related to the leaking problem due to the crack between jointing of IBS wall and roof, jointing material is not long-lasting, and easy to damage under drastic changes in hot and dry climate conditions. The leakage between the joints has given the poor physical appearance of the house." Respondent R6.

Most developers received complaints from customers about cracking problems in the walls and roofs. These have cause to leaking problem and give the bad aesthetic value of the house. There is also happened in IBS precast construction which concerned the IBS manufacturers on the business opportunities, technology, quality in production, and market reputation of the housing construction (Marsono, Md. Tap, Ching \& Makhtar, 2006). This issue has been given a bad reputation to the IBS construction performance. Nowadays, Malaysia still faces great challenges in finding affordable materials to improve current IBS materials, especially on concrete types. Thus, the IBS system with the highly durable specification is indispensable to ensure the homebuyers will buy an affordable house with excellent physical appearance and a long life span. The lightweight steel panel is the potential to provide appropriate system development on the lightweight specification for affordable housing construction with high quality and good physical appearance. By using a lightweight steel panel, the house can be constructed with cold form steel as the main structure, together with a cement board or gypsum board for interior wall, and decorative sandwich metal panel or decorative wood plank as exterior wall. The decorative exterior wall will increase the production value of affordable housing. Jang, Baek, Yoon \& Choo (2018) stated that the decorative pattern applied on walls and features of building space will increase the level of customer's visual complexity. On the other hand, Pan, Gibb \& Andrew (2007) also determined that the building color and texture (physical appearance) will increase customer satisfaction. Furthermore, the excellent physical appearance can increase the value of the house trough elegant decorative design. There is also will eliminate the mindset of the occupant that the IBS system has a lower quality of housing construction (Mydin, Sani \& Taib, 
2014). Therefore, the development of the lightweight steel panel system with less crack risk in jointing and have a unique decorative design could be eliminating the skeptical mindset towards IBS system performance.

\subsubsection{Flexibility}

Housing construction with a lightweight steel panel system is high flexibility and easy to adapt to any changes. It is important to fulfill the human's social culture and norm when having their own house. This is agreed by respondent $\mathrm{R} 1, \mathrm{R} 2$, and $\mathrm{R} 4$ which mention renovation be the main target when buying the house.

“..Malaysian people like to do extend their house. So many questions come out from them about how to extend the house. Such a long time ago we have used IBS precast system, it is a problem arise when the occupant wants to break up the wall. But if you used this lightweight steel panel system may they can open and install the wall again but needs help from the expertise." Respondent R1.

"..From my side of view such as the IBS system, we do not know why the majority of people have the mindset which the first question before buying the house we have been asking about how to renovate the house. So, it is the main issue whether this system suit renovation activity or not. This type of question is difficult to answer." Respondent R4.

Every people own their own house dreaming to have a big family house with enough size and room for every family member. Affordable houses especially own by the young married couple have a big plan to expand their family. Sooner or later they need to plan a new design of house layout because of the increased number of family members (Brezar, 2014). Strategy to install the elements of flexible design in lightweight steel panel system configuration is crucial to enables the renovation of houses across time, especially for middle and low-income families (Hatipoglu \& Ismail, 2019). Generally, middle and lower-income earners just eligible to buy a small house especially for the young couple just get started their own carrier. Thus, there is an increasing need to include adaptability as a design principle for lightweight steel panel system development holding the reason for both environmental and economic aspects to provide a building fit current and future activity of modification work ( $\mathrm{Li}, 2014)$.

Many studies have encouraged the utilization of sustainable housing product material in housing construction. The house must be designed to be easily constructed and operated with reuse and recycle materials and components. The specification of the product component must be handily maintained, refurbished and renovated when required (Olanrewaju, Lee, Seong, Mine \& Teng, 2017). This will be the basis for the introduction of a lightweight steel panel system implication system in affordable housing development. Various reasons caused in the uptake of steel material to be used in an affordable housing project. Steel material component has been taken as one of the research study conducted by Krueger, Stoker \& Gaustad (2019) in comparison with glulam material because steel can make by local manufacturers, can easily reusable, recyclable ability and durable and require low maintenance. The research has found out that steel gets credit for recycling ability to compare with glulam materials. Thus, the recycling ability of steel products will reduce the waste generation produced from the housing construction industry.

\subsubsection{Smart System}

Developers for affordable housing often face critical issues with concrete material products. They commonly face the problem of floor cracking especially on the joint part. Respondents R1, R3, R4, R5, and R6 hope that the lightweight steel panel system will solve the problem of the current IBS system and be as thee really smart system. As respond given by respondent R2 explain the reason for the utilization of the IBS system whit less mortar consumption. Meanwhile respondent R3 preferred to accept the dry housing system due to the smart and clean of the project site.

"..We do not give them any condition for the type of materials that they used to build the house. The reason they used lightweight concrete is that they can reduce mortar consumption until $40 \%$. They said we have eliminated the mixing cement and sand activity, our site not dirty, then no need to use much labor to do plastering. Also, less site arrangement for wet mixing mortar which we used skim code rather than cement plaster. We also feel the valuable impact of the skim code finishing." Respondent R2.

"..Actually, the advantages of IBS are like I said just now, it is dry construction which means the construction is clean and smart, it is not like the conventional system which they have waste from cement, wood, and iron.” Respondent R3

Respondent R5 state the experience in using precast concrete for affordable housing development in South Malaysia. The precast system needs a complex management system, whereas the workers must have high skill in setting up the system. The site also still looks messy if the precast panel is not well organized. Therefore, the developer sees another type of IBS material which has given them satisfaction is by utilization of steel frame house with wall interior and exterior wall using gypsum board. This coincides with research conducted by Kim (2019) steel section and wall configuration in the development of the modular building. Kim (2019) has set up the modular building by using a double layer of gypsum board, followed by the installation of insulation in the space between the interior and exterior walls. The material specification of this system has given more economical advantage. Other than that house made from steel structure also superior strength-to-weight ratio used simple production process and lower energy consumption. 
Paton-Cole \& Gad (2017) also define the solution for the builder to get more on economic performance on the utilization of cold-form steel structure in housing construction. Cost-saving is getting from the optimization of structure and minimize the amount of steel. Additionally, the main target of the project is focused on the final cost of the house, it achieved by minimizing the circulation area and maximize the living and bedroom space. The lightweight steel panel system can be a superior alternative house system by various advantages includes allow easy implementation in terms of construction and constructive compatibility, and also in terms of costs. A developed country has often used steel material for the housing industry because of the availability of steel resources. In the case of Malaysia, the exploration of steel material in the affordable housing industry is crucial for the need to get an economical system mechanism. Such in South Africa, the lightweight steel frame industry enters the fast growth and the housing methods become popularly utilized by suppliers and builders (Barnard, 2009). The lightweight steel panel system would be a great alternative building method for the affordable housing project and also be a viable option on which building method to use.

\subsection{Summary Findings of Potential Implementation of Lightweight Steel Panel System}

This part summary the finding from the interview sessions. Based on finding just four potential factors were find out from the analysis process. The finding reveals that 5 benefits of lightweight steel panel system implementation based on the developer's perspective are (i) faster installation work, (ii) maintenance work, (iii) physical appearance, (iv) flexibility, and (v) smart system. The summaries finding of the potential requirement of a lightweight steel panel system stated as follow in Table 4 below:

Table 4 - Summary Findings

\begin{tabular}{|c|c|c|}
\hline Main Factor & Respondent & $\begin{array}{l}\text { Benefit of Lightweight Steel Panel System } \\
\text { Implementation }\end{array}$ \\
\hline Faster Installation Work & $\mathrm{R} 1, \mathrm{R} 3, \mathrm{R} 4, \mathrm{R} 5$ & $\begin{array}{l}\text { - Faster installation } \\
\text { - Lower cost and quality housing } \\
\text { - Faster construction with less defect issue } \\
\text { - Price reduction due to faster delivery, save cost } \\
\text { and time. }\end{array}$ \\
\hline Maintenance Work & $\mathrm{R} 2, \mathrm{R} 4, \mathrm{R} 6$ & $\begin{array}{l}\text { - Lower maintenance within } 10 \text { years } \\
\text { - Quality system with lower maintenance } \\
\text { - The lower price of metal sheet panel } \\
\text { - Corrosion resistance }\end{array}$ \\
\hline Physical Appearance & R1, R3, R4, R6 & $\begin{array}{l}\text { - QLASSIC test } \\
\text { - Smooth wall } \\
\text { - Smoothjointing } \\
\text { - Less water leakage }\end{array}$ \\
\hline Flexibility & $\mathrm{R} 1, \mathrm{R} 2, \mathrm{R} 4$ & $\begin{array}{l}\text { - Easy modification } \\
\text { - Easy refurbishment }\end{array}$ \\
\hline Smart System & $\mathrm{R} 1, \mathrm{R} 3, \mathrm{R} 4, \mathrm{R} 5, \mathrm{R} 6$ & $\begin{array}{l}\text { - Overall advantages (less labor, clean site, no } \\
\text { messy, simple system, easy transportation, easy } \\
\text { material supply) } \\
\text { - Hybrid system } \\
\text { - Easy construction in term of constructive } \\
\text { compatibility }\end{array}$ \\
\hline
\end{tabular}

\section{Conclusion}

This paper gives a clear understanding of the potential factors of a lightweight steel panel system for an affordable housing project in Malaysia. View amongst developers of affordable housing projects about the proposed system is 
important as guidance to the lightweight steel panel implementation. Obviously, several developers have been introduced by any type of IBS system include the steel framing concept. In fact, they agree the lower cost, short construction time and quality housing is the main reason for the success of the implementation. The lightweight steel panel system can be implemented by offering to the middle, income earner, the affordable housing price below RM200, 000 with standard housing quality. This can be fulfilled rearrange the housing supply chain by the developers be as the main actors in the manufacturing team while the contractor is focusing on installation work. However strong collaboration between stakeholders is very important to ensure the successful implementation of the lightweight steel panel system to fulfill affordable housing demands. Therefore, further studies are encouraged to test on the contractor's perception towards the requirement of implementation of a lightweight steel panel system in the affordable housing project.

\section{Acknowledgement}

The authors would like to thank the Universiti Tun Hussein Onn Malaysia for supporting this research work

\section{References}

Aliyu, A.A., Kasim, R. \& \& Martin,D. (2011). Impact of Violent Ethno-Religious Conflicts on Residential Property Value Determination in Jos Metropolis of Northern Nigeria: Theoretical Perspectives and Empirical Findings, Morden Applied Science, 5 (5), pp. 171-183

Andrade, J. B., Bragança, L., \& Camões, A. (2016). Steel Sustainability Assessment. Do BSA Tools Really Assess Steel Properties?, Journal of Constructional Steel Research, 120, pp. 106-116

Azmi, N., Bujang, A. A., Jiram, W. R. A., \& Zarin, H. A. (2016). The Fundamental of Housing Affordability \& Affordable Houses: a Review. In Knowledge, Service, Tourism \& Hospitality: Proceedings of the Annual International Conference on Management and Technology in Knowledge, Service, Tourism \& Hospitality 2015 (SERVE 2015), Bandung, Indonesia, pp. 203

Barker, C. \& Pistrang, N. (2005). "Quality Criteria under Methodological Pluralism: Implications for Conducting \& Evaluating Research”, American Journal of Community Psychology, 35(3/4), pp. 201-212

Baker, S., Gersten, R., \& Lee, D. S. (2002). A Synthesis of Empirical Research on Teaching Mathematics to LowAchieving Students. The Elementary School Journal, 103(1), pp. 51-73

Barnard, D. (2011). Light Steel Construction and Modular Homes as Alternative Building Methods in South Africa. Degree of B.Sc (Hons) (Construction Management). Faculty of Engineering, Built Environment and Information Technology University of Pretoria

Berhad, C. (2013). Housing the Nation: Policies, Issues \& Prospects. Kuala Lumpur: Cagamas Holdings Berhad

Blismas, N. (2007). Off-Site Manufacture in Australia: Current State \& Future Directions. Cooperative Research Centre for Construction Innovation

Blismas,N., Pasquire, C., \& Gibb, A. (2006). Benefits Evaluation for Off-Site Production in Construction, Construction Management \& Economics (February 2006), 24, pp. 121-130

Bujang A. A., Shape N. A. S., Abu Zarin, H., \& Ismail. A. (2017). Factors Influencing the Housing Affordability Stress among Bumiputera. International Journal of Real Estate Studies, 11(4)

Brezar, V. (2014). Changes: the Bridge between the Past \& the Future. International Journal for Housing Science \& Its Applications, 38(3)

CIDB (2018). Projection of Construction and Material Demand for Projects Awarded. Business \& International Division Policy \& Corporate Sector Construction Industry Development Board (CIDB) Malaysia

CIDB (2007). Construction Industry Master Plan (CIMP) 
CIDB (2004). Managing Construction Procurement Risks. Pretoria: First Edition of CIDB document 1005

CIDB (2003). Roadmap 2003-2010. Construction Industry Development Board Malaysia, Kuala Lumpur

CIDB (1999). IBS Strategic Plan 1999 -2003, Construction Industry Development Board (CIDB), Kuala Lumpur, 1999, pp: 4-6

Cheng, X., Zhao, X., \& Chen, Y. (2011). Overall Investigation of Affordable Residential Housing in China. In 2011 International Conference on Electric Technology \& Civil Engineering (ICETCE) pp. 539-543

Cole, V. P., \& Gad, E. F. (2017). Understanding the Benefits of Constructing a Residential House with a Heart of ColdFormed Steel. Epic Series in Education Science, 1, pp. 288-296

Department of Statistics Malaysia (2016). Population Distribution \& Basic Demographic Characteristics-Population \& Housing Census of Malaysia 2016. Department of Statistics, Malaysia, Putrajaya, Malaysia

Economic Planning Unit. (2015). Rancangan Malaysia Kesebelas (Eleventh Malaysia Plan)

Ern, P., \& Kasim, N. (2012). E-readiness for Industrialised Building Systems (IBS) components management: Exploratory Study in Malaysian Construction Projects. ICIMTR 2012-2012 International Conference on Innovation, and Technology Research (2012) 454-459

Fathi, I.M.S., Abedi, M., \& Mirasa, A.K. (2012). Construction Industry Experience of Industrialised Building System in Malaysia . 9th International Congress on Civil Engineering (9ICCE), pp. 1

Fiske, D., \& Sheweder, R. (1986). Metatheory in Social Science: Pluralisms and Subjectivities, University of Chicago Press, Chicago

Gan, X., Zuo, J., Wen, T., \& She, Y. (2019). Exploring the Adequacy of Massive Constructed Public Housing in China. Sustainability, 11(7)

Gan, X. Zuo, J., Ye, K., Chang, R., \& Zillante, G. (2016). Are Migrant Workers Satisfied with Public Rental Housing? a Study in Chongqing, China. Habitat Int. 2016, 56, pp. 96-102

Gibb, A., \& Isack, F. (2003). Re-Engineering Through Pre-Assembly: Client Expectations \& Drivers. Building Research \& Information, 31(2), pp. 146-160

Goh, B. H. (1998). Forecasting Residential Construction Demand in Singapore: A Comparative Study of the Accuracy of Time Series, Regression \& Artificial Neural Network Technique. Engineering Construction \& Architectural Management, 5(3), pp. 261-75

Goodier, C., \& Gibb, A. (2007). Future opportunities for offsite in the UK. Construction Management \& Economics, 25(6), pp. 585-595

Habraken, John, N., Teicher, \& Jonathan (2005). Palladio's Children. London: Taylor \& Francis

Hacker, J. H., \& Gorges, J. A. (1998). Residential Steel Design \& Construction (New York: McGraw-Hill Companies)

Harty, C., Goodier, C.I., \& Soetanto, R. (2006). The Futures of Construction: A Review of Future Studies. Construction Management \& Economics (in press)

Haron, N. A., Rahman, H. A., Wang, C., \& Wood L. C. (2015). Quality Function Deployment Modelling to Enhance Industrialised Building System Adoption in Housing Projects ISSN: 1478-3363 (Print) 1478-3371 (Online) Journal homepage: Http://Www.Tandfonline.Com/Loi/Ctqm20

Haron, N. A., Hamzah, A. R., \& Mahanim, H. (2009). A Literature Review of the Advantages \& Barriers to the Implementation of Industrialized Building System (IBS) in the Construction Industry. Malaysian Construction Research Journal, 4(1), pp. 10-14 
Haron, S. A., Paim, L., \& Yahaya, N. (2005). Towards Sustainable Consumption: an Examination of Environmental Knowledge Among Malaysians. International Journal of Consumer Studies, 29(5), pp. 426-436

Hatipoglu, H. K., \& Ismail, S. H. (2019). Flexibility: From Tent to Modern Houses in Turkey Evaluation \& Guidelines. In IOP Conference Series: Materials Science and Engineering. 471(8), pp. 082070

Jang, J. Y., Baek, E., Yoon, S. Y., \& Choo, H. J. (2018). Store Design: Visual Complexity \& Consumer Responses. International Journal of Design, 12(2)

Jansen, S., Coolen, H., \& Goetgeluk, M. (2011). The Measurement \& Analysis of Housing Preferences \& Choice, Delft University, Delft

Jovanovic, J., Grbic, J., \& Petrovic, D. (2011). Prefabricated Construction in Former Yugoslavia. Visual and Aesthetic Features and Technology of Prefabrication. In Proceedings of the Post War Modern Architecture in Europe, Berlin, Germany, 22-24 July 2011

Kadir, M.R.A., Lee, M.S., Jaafar, M.S., Sapuan, S.M., \& Ali, A.A.A. (2005). Factors Affecting Construction Labour Productivity for Malaysian Residential Projects. Structural Survey, 23(1), pp. 42-54

Kirsch, \& Sulllivan (1992). Methods and Methodology in Composition Research, Southern Illinois University, Illinois

Kwan, C. S., Kwan, Y. S., \& Kwan, S. S. (2016). U.S. Patent Application, 14(957), pp. 637

Kim, J (2019). Development of Modular Building Systems Made of Innovative Steel Sections \& Wall Configurations. Degree of Master of Philosophy (Engineering). School of Civil Engineering \& Built Environment Faculty of Science \& Engineering. The Queensland University of Technology

Kolo, S. J., Rahimian, F. P., \& Goulding, J. S. (2014). Offsite Manufacturing Construction: a Big Opportunity for Housing Delivery in Nigeria. Procedia Engineering, 85, pp. 319-327

Krueger, K., Stoker, A., \& Gaustad, G. (2019). "Alternative" Materials in the Green Building \& Construction Sector: Examples, Barriers, \& Environmental Analysis. Smart \& Sustainable Built Environment

Lawson, R. M., Popo-Ola, S. O., Way, A., Heatley, T., \& Pedreschi, R. (2010). Durability of Light Steel Framing in Residential Applications. Proceedings of The Institution of Civil Engineers-Construction Materials, 163(2), pp. 109121

Lawson, R. M., Ogden, R. G., Pedreschi, R., \& Popo Ola, S. O. (2005). Pre-Fabricated Systems in Housing Using Light Steel \& Modular Construction. Steel Structures, 5, pp. 477-48

Lawson, R. M., Gorgolewski, M., \& Grubb, P. J. (2003). Building Design Using Cold-formed Steel Sections: Light Steel Framing in Residential Construction. The Steel Construction Institute, pp. 301

Li, S. (2014). A View of Flexible Housing in China. International Journal of Architectural \& Environmental Engineering, 8(4), pp. 958-962

Lim, X. Y. (2019). Strategies for Affordable Housing Delivery. Doctoral Dissertation: UTAR

Maimun, N. A., Ismail, S., Junainah, M., Razali, M. N., Tarmidi, M. Z., \& Idris, N. H. (2018). An Integrated Framework for Affordable Housing Demand Projection \& Site Selection. In IOP Conference Series: Earth and Environmental Science, 169(1), pp. 012094

Malaysia Industrial Development Authority (2011). Basic Metal Products Industry. (Online). Available: Http://Www.Mida.Gov.My

Marsono, A. K., Md. Tap, M., Ching, N. S., \& Makhtar, A. M. (2006). Simulation of Industrialized Building System Components Production. In Proceedings of the 6th Asia-Pacific Structural Engineering \&Construction Conference (APSEC 2006), pp. 5-6 
Mydin, M. O., Sani, N. M., \& Taib, M. (2014). Industrialized Building System in Malaysia: A Review. In MATEC Web of Conferences. EDP Sciences, 10, pp. 01002

Mohit, M. A., Ibrahim, M., \& Rashid, Y. R. (2010). Assessment of Residential Satisfaction in Newly Designed Public Low-Cost Housing in Kuala Lumpur, Malaysia. Habitat International, 34(1), pp. 18-27

Olanrewaju, A., \& Tan, S. Y. (2018). An Exploration into Design Criteria for Affordable Housing in Malaysia. Journal of Engineering, Design \& Technology

Olanrewaju, A. L., Lee, L. T., Seong, Y. T., Mine, N., \& Teng, C. T. (2017). An Investigation into Design Criteria for Affordable Housing Supply. In MATEC Web of Conferences, EDP Sciences. 103, pp. 03013

Olanrewaju, A., Lee, L.T., Tan, S.T., Naoto, M., Nizamani, Z., \& Aziz, A.A. (2016). Analysis of Economic Determinants of Affordable Housing Prices. Integrated Solutions for Infrastructure Development, pp 1-6

Pan, W., Gibb, A., \& Dainty, A. R. J. (2008). Leading UK Housebuilders Utilization of Offsite Construction Method, Building Research \& Information, 36(1), pp. 56-67

Pan, W., Gibb, A. G. F., \& Andrew, R. J. D. (2007). Perspectives of UK House Builders on The Use of Offsite Modern Methods of Construction, Construction Management \& Economics (February2007), 25, pp. 183-194

Pan, Y. H., Wong, K. W., \& Hui, C. M. (2007). Cost Comparison between the Construction of Lightweight \& Conventional Partitions in Chongqing, China. International Journal of Construction Management, 7 (1)

Pan, W. (2006). A Decision Support Tool for Optimizing the Use of Offsite Technologies in Housebuilding, Unpublished Ph.D. Thesis, University of Loughborough, UK

Pan, W., Gibb, A.G.F., \& Dainty, A.R.J. (2006). Perspectives of UK Housebuilders on The Use of Offsite Modern Methods of Construction. Construction Management and Economics (In Press)

Paton-Cole, V. P., \& Gad, E. F. (2017). Understanding the Benefits of Constructing a Residential House with a Heart of Cold-Formed Steel. EPiC Series in Education Science, 1, pp. 288-296

Paudel, P., Dulal, S., Bhandari, M., \& Tomar, A. (2016). Study on Pre-fabricated Modular \& Steel Structures. International Journal of Civil Engineering (SSRG-IJCE), 3(5)

Rahadi, R. A., Wiryono, S. K., Koesrindartoto, D. P., \& Syamwil, I. B. (2015). Factors Influencing the Price of Housing in Indonesia. International Journal of Housing Markets \& Analysis, 8(2), pp. 169-188

Rahim, A. A., Hamid, Z. A., Zen, I. H., Ismail, Z., \& Kamar, K. A. M. (2012). Adaptable Housing of Precast Panel System in Malaysia. Procedia-Social \& Behavioral Sciences, 50, pp. 369-382

Rahman, H. A., Wang, C., \& Arrifin, N. (2015). Identification of Risks Pertaining to Abandoned Housing Projects in Malaysia, Journal of Construction Engineering, 2015, pp. 1-12

Rahman, H. A., Wang, C., Wood, L. C., \& Khoo, Y. M. (2014). Defects in Affordable Housing Projects in Klang Valley, Malaysia. Journal Of Performance Of Constructed Facilities, 28(2), pp. 272-285

Russell, S., Weston, M., Goswami, Y. \& Doll, M. (2011). Flex House. Proceeding of the Asme $20115^{\text {th }}$ International Conference on Energy Sustainability on Energy Sustainability, Washington, Dc, USA

Schmidt, III, R., Vibaek, K. S., \& Austin, S. (2014). Evaluating the Adaptability of an Industrialized Building Using Dependency Structure Matrices. Construction Management and Economics, 32(1-2), pp. 160-182 
Soetanto, R., Goodier, C.I., \& Harty, C. (2006). Synthesizing Emerging Issues within Key Futures Study Reports in Construction. Construction in the XXI Century: Local And Global Challenges, Joint International Symposium of CIB Working Commissions W55, W65 \& W86, Rome, pp. 18-20

Sulaiman, N., Baldry, D., \& Ruddock, L. (2005). Can Low-Cost Housing in Malaysia be considered as Affordable Housing? 12th Annual European Real Estate Society Conference. 15-18 June Dublin: ERES

Sulaiman, S., Jusoh, A., Ying, K. S., \& Soheilirad, S. (2019). Customer Satisfaction in Conquas and QLASSIC Certified Housing Projects. Journal of Public Value and Administration Insights, 2(1), pp. 10-17

Tan, W.K. (2013). Housing the Nation: Policies, Issues \& Prospects. Kuala Lumpur: Cagamas Holdings Berhad

United Nations (1996). Habitat Agenda and Istanbul Declaration: Second United Nations Conference on Human Settlements, Istanbul, Turkey 3-14 June 1996. United Nations Department of Public Information

Veljkovic, M., \& Johansson, B. (2016). Light Steel Framing for Residential Buildings, Thin. Wall. Struct, 44(2006), $1272-1279$

Yap, J. B. H., Yong, P. S., \& Skitmore, M. (2019). Analyzing the Desired Quality of Housing in the Klang Valley Region, Malaysia. Pacific Rim Property Research Journal, pp. 1-16

Ying, X. L., Olanrewaju, A., \& Tan, S.Y. (2015). Strategies for Affordable Housing Delivery. Australian Journal of Basic \& Applied Sciences, 9 (25), pp. 118-124

Yu, Y. C., Yashiro, T., Yoshida, S., \& Qiu, Z. (2015). Comparative Studies on the Regional Differences of Modularity Design Tendency Between the United States and Japan J. Asian Architecture and Building Engineering, 14(1), pp. 4956 